\section{Analisis Yuridis Tentang Pencabutan Hibah Orang Tua Kepada Anak Kandungnya Dalam Perspektif Perspektif Kompilasi Hukum Islam (Studi Putusan Nomor 1934/Pdt.G/2013/ PA.Mdn)}

\author{
Mustamam 1 \\ tamambar@yahoo.com \\ Zulfan $\mathbf{A Z}^{\mathbf{2}}$
}

\begin{abstract}
A grant is a type of gift made by one person to another when the donor and recipient of the grant is still alive. Grants, in any law, are basically irrevocable unless they meet certain conditions.

A grant is the giving of an object voluntarily and it is done without reward from someone to another person who is still alive to have. A grant cannot be withdrawn except for a grant from the parent to the child, that is to say that the ability to withdraw the grant only applies to parents who donate something to their child. It means that the parents give grants to their children by paying attention to the values of justice.

The results of this study indicate that the Religious Court Medan Number 1934 / Pdt.G / 2013 / PA.Mdn which was decided on 26 May 2014 regarding the land given by the grantor was declared revoked or cancelled because the fact shows that first, the life of the grantor at that time was very poor and suffered from diabetes. Second, according to the plaintiff, the grantees had stolen the plantation owner's land certificate. Third, according to witnesses, the grantees refused to support or help the grantor when he was poor. Revocation of this grant is also in accordance with Article 212 of the Compilation of Islamic Law which states that a grant cannot be revoked or cancelled unless it is a grant from the parents to their biological child. This is why the court declared that the grant was null and void.
\end{abstract}

Keywords : Grant, Revocation, Grantor, Grantees.

${ }^{1}$ Dosen Fakultas Hukum UISU

${ }^{2}$ Alumni Magister Hukum Fakultas Hukum UISU

\section{Abstrak}

Hibah adalah jenis pemberian yang dilakukan oleh seseorang kepada yang lain ketika pemberi dan penerima hibah masih hidup. Hibah, dalam undang-undang apa pun, pada dasarnya tidak dapat dibatalkan kecuali memenuhi persyaratan tertentu.

Hibah adalah pemberian suatu benda secara sukarela dan tanpa imbalan dari seseorang kepada orang lain yang masih hidup untuk dimiliki. Hibah tidak dapat ditarik kembali kecuali hibah dari orang tua kepada anaknya, artinya kebolehan menarik kembali hibah hanya berlaku bagi orang tua yang menghibahkan sesuatu kepada anaknya, maksudnya agar orang tua dalam memberikan hibah kepada anak-anaknya dengan memperhatikan nilai-nilai keadilan.

Hasil penelitian ini menunjukkan bahwa Pengadilan Agama Medan Nomor 1934 / Pdt.G / 2013 / PA.Mdn yang diputuskan pada 26 Mei 2014 tentang tanah yang diberikan atau diberikan oleh pemberi hibah dinyatakan dicabut atau dibatalkan karena fakta menunjukkan bahwa pertama, kehidupan pemberi pada saat itu sangat miskin dan menderita penyakit diabetes. Kedua, menurut penggugat penerima hibah telah mencuri sertifikat tanah pemilik perkebunan. Ketiga, menurut saksi, penerima hibah menolak untuk mendukung atau membantu pemberi hibah ketika ia miskin. Pencabutan hibah ini juga sesuai dengan pasal 212 Kompilasi Hukum Islam yang menyatakan hibah tidak dapat dicabut atau dibatalkan kecuali hibah dari orang tua kepada anak kandung mereka. Inilah mengapa pengadilan menyatakan bahwa hibah itu batal demi hukum.

Kata kunci : Hibah, Pencabutan, Pemberi, Penerima.

\section{Pendahuluan}

\section{A. Latar Belankang}

Antara prinsip-prinsip dasar dan umum dalam syari'at Islam adalah mudah dan memudahkan (al-yusra wa al-taisir), toleransi dan keseimbangan (al-tasamuh wa al-i'tidal) serta menghindari kesulitan dan kesempitan dalam ketentuan hukum syariah. Islam adalah 
Media Komunikasi dan Informasi Hukum dan Masyarakat

sebagai agama dan juga sebagai hukum. Berbicara tentang hukum secara sederhana maka yang akan muncul adalah peraturanperaturan atau seperangkat norma yang mengatur tingkah laku dalam masyarakat. Dalam sistem yuridis terdapat istilah al-ahkam al-khamsah yakni penggolongan hukum yang lima yaitu mubah, sunah, makruh, wajib, dan haram.

Segala aturan hukum tersebut berfungsi untuk mengintegrasikan kepentingan manusia sehingga tercipta suatu keadaan yang tertib. Tujuan dari hukum-hukum tersebut adalah almaqasid al-khamsah yaitu memelihara agama, memelihara jiwa, memelihara akal, memelihara keturunan dan memelihara harta.

Perjalanan kehidupan menimbulkan pengaruh dan akibat hukum kepada lingkungan dan dengan orang sekitar. Kelahiran, pernikahan, kematian dan perpindahan harta diatur secara detail dalam Islam. Agama Islam memberikan tuntunan bagaimana cara memindahkan harta kekayaan dari seseorang pada orang lain. Berbagi harta ada bermacammacam bentuknya ada yang dengan cara sedekah, hadiah, hibah, waris ataupun wasiat. Berbagi harta seperti yang telahdisebut di atas dapat pula disebut dengan pemindahan hak atas harta yang mana dari semua itu memiliki aturan masing-masing. Persamaan dari macammacam bentuk pemindahan hak atas harta di atas adalah sama-sama perpindahan harta dari seseorang kepada orang lain.

Penelitian kali ini peneliti fokus dalam pembahasan hibah. Menurut kamus ilmiah popular internasional hibah adalah pemberian, sedekah, pemindahan hak. $^{3}$ Ada pula yang mengatakan hibah berarti pemberian yang

3Budiono, Kamus Ilmiah Popular Internasional, Surabaya : Alumni, 2005, hal. 217 dilakukan secara sukarela dalam mendekatkan diri kepada Allah SWT, pendapat lain mengatakan pemberian tanpa mengharapkan imbalan sebagai upaya taqorrub kepada Allah SWT artinya sesuatu yang dapat meningkatkan keimanan dan ketaqwaan seseorang dan sebagai upaya mengurangi kesenjangan sosial. ${ }^{4}$

Anisitus Amanat menjelaskan bahwa pemberi hibah menyerahkan hak miliknya atas sebagian atau seluruh harta kekayaannya kepada pihak lain tanpa imbalan apa-apa dari penerima hibah. Barangkali karena tidak adanya kontra prestasi dalam hibah semacam itu, maka pembentuk undang-undang membuat aturan yang mewajibkan penerima hibah untuk memasukkan kembali semua harta yang telah diterimanya itu ke dalam harta warisan pemberi hibah guna diperhitungkan kembali. ${ }^{5}$

Perkara hibah dilarang untuk ditarik kembali. Penarikan kembali atas sesuatu pemberian (hibah) adalah merupakan perbuatan yang diharamkan meskipun hibah tersebut antara dua orang bersaudara atau suami istri. Adapun hibah yang dapat ditarik kembali hanyalah hibah yang dilakukan atau diberikan orang tua kepada anaknya.

Menurut hadis Ibnu Abbas, Rasulullah Saw, bersabda bahwa :

Artinya:"Orang meminta kembali
hibahnya adalah laksana anjing yang
muntah kemudian dia memakan kembali
muntahnya itu."

Kompilasi Hukum Islam merupakan salah satu hukum materiil Pengadilan Agama

${ }^{4}$ Abdul Manan, Aneka Masalah Hukum Perdata Islam di Indonesia, Kencana, Jakarta 2006, hal.132

${ }^{5}$ Anisitus Amanat, 2001, Membagi Warisan Berdasarkan Pasal-Pasal Hukum Perdata BW, PT Raja Grafindo Persada, Jakarta, hal. 70

${ }^{6}$ Abdul Manan, Op-Cit, hal. 137 
Media Komunikasi dan Informasi Hukum dan Masyarakat

yang berhubungan langsung dengan penelitian ini. $\mathrm{KHI}$ adalah Kompilasi Yuridis kumpulan atau himpunan kaidah-kaidah yuridis yang disusun secara sistematis yang terdiri dari tiga buku. Dalam Kompilasi Yuridis hibah terdapat pada buku III bab VI pasal 212 yang berbunyi "Hibah tidak dapat ditarik kembali, kecuali hibah orang tua kepada anaknya."

Berdasarkan pasal di atas
sangat tegas dijelaskan bahwa hibah tidak dapat ditarik kembali kecuali hibah dari orang tua kepada anaknya, artinya kebolehan menarik kembali hibah hanya berlaku bagi orang tua yang menghibahkan sesuatu kepada anaknya, maksudnya agar orang tua dalam memberikan hibah kepada anakanaknya dengan memperhatikan nilainilai keadilan.

Selanjutnya pemberian hibah ibu rumah tangga (berusia 71 tahun) kepada anakanaknya tersebut didasari pada pertimbangan agar 6 (enam) orang anaknya tersebut bersedia mengurus dirinya disaat usia yang menjelang senja. Namun harapan orang tua tersebut ternyata sangat bertolak belakang. Hal ini terlihat jelas di dalam dalil gugatan orang tua tersebut menerangkan bahwa tidak satu pun dari anak-anaknya yang mau memperhatikan dirinya. Sehingga kehidupannya sangat memprihatinkan, bahkan untuk memenuhi kebutuhan sehari-hari, orang tua itu selalu meminta-minta kepada tetangga, berdasarkan keterangan saksi-saksi di muka persidangan kehidupan orangtuanya sangat memprihatinkan, selain itu orangtua itu juga dalam keadaan menderita penyakit diabetes.

\section{B. Rumusan Masalah}

Berdasarkan uraian-uraian yang telah dipaparkan di latar belakang penelitian ini, maka dapat ditarik sebuah permasalahan sebagai berikut :

1. Bagaimanakah pengaturan dan dasar hukum tentang hibah?

2. Bagaimana pembatalan hibah orang tua terhadap anak kandungnya dalam perspektif kompilasi hukum islam ?

\section{Metode Penelitian}

Penelitian ini menggunakan jenis penelitian yuridis normatif. Penelitian yuridis normatif dilakukan dengan cara menelaah dan menginterpretasikan hal-hal yang bersifat teoritis yang menyangkut asas, konsepsi, doktrin dan norma hukum yang bersangkutan dengan pencabutan hibah orang tua kepada anak kandungnya dalam perspektif perspektif kompilasi hukum islam.

Penelitian yuridis normatif adalah pendekatan yang dilakukan berdasarkan bahan hukum utama dengan cara menelah teori-teori, konsep-konsep, asas-asas serta peraturan perundang-undangan yang berhubungan dengan penelitian ini.

Berdasarkan sifatnya maka penelitian bersifat deskriptif bermaksud untuk memberikan gambaran secara jelas dan terprinci mengenai tinjauan.

Analisis data yang digunakan dalam penelitian ini adalah analisis secara kualitatif yaitu uraian yang dilkukan peneliti terhadap data yang terkumpul tidak menggunakan statistik atau matematika ataupun sejenisnya tetapi berupa uraian-uraian kalimat yang tersusun secara sistematis sesuai dengan permaslahan yang dibahas dalam penelitian ini. 
Media Komunikasi dan Informasi Hukum dan Masyarakat

\section{Hasil dan Penelitian}

A. Pengaturan dan Dasar Hukum Tentang Hibah

Dalam kehidupan sehari-hari khususnya dalam masyarakat yang semakin maju, maka perjanjian merupakan suatu yang senantiasa ditemukan dalam kehidupan sehari-hari. Perjanjian merupakan suatu sendi yang penting di dalam melakukan suatu pemberian atau penghibahan.

Bentuk perjanjian ini biasanya merupakan suatu rangkaian perkataan yang mengandung janji-janji atau kesanggupan seseorang yang memenuhi prestasinya biasanya diucapkan atau tertulis, hal tersebut dilakukan untuk memberikan pengertian lengkap dan sempurna mengenai istilah perjanjian yang diinginkan para pihak. Dalam hal ini setiap ahli hukum memberikan istilah perjanjian yang berbeda-beda, yaitu dalam bahasa Belanda disebut Overnkomst dan hukum perjanjian adalah Overeeenkomstenderecht.

\section{Menurut Wirjono Projodikoro} bahwa perjanjian adalah suatu perbuatan mengenai harta benda antara dua pihak dalam satu pihak berjanji atau dianggap untuk melaksanakan suatu hal, sedangkan pihak yang lain berhak menuntut perjanjian itu. ${ }^{8}$ Menurut Subekti perjanjian adalah suatu peristiwa dimana seorang berjanji kepada orang lain atau dimana dua orang itu saling berjanji untuk melaksanakan suatu dalam bentuk perjanjian berupa suatu rangkaian perkataan yang diucapkan atau ditulis. ${ }^{9}$

${ }^{8}$ Wirjono Projodikoro, Asas-asas Hukum Perjanjian, Sumber Bandung, Jakarta 1980, hal. 9.

${ }^{9}$ Subekti, Hukum Perjanjian, Intermasa, Jakarta,
Membedakan antara perikatan dan perjanjian adalah bahwa perjanjian itu dilahirkan oleh perikatan dan perikatan lahir karena adanya perjanjian. Jadi pada hakekatnya perikatan itu lebih luas dari perjanjian karena perikatan mencakup semua ketentuan dalam buku ketiga KUHPerdata, baik itu perikatan yang bersumber dari perjanjian maupun perikatan yang bersumber dari Undang-Undang.

Hibah adalah pemberian yang dilakukan oleh seseorang kepada pihak lain yang dilakukan ketika masih hidup. Menurut pengertian bahasa hibah berarti "pemberian" baik berupa harta benda maupun yang lainnya. Menurut istilah bahasa hibah adalah memberikan hak memiliki sesuatu kepada orang lain dengan tanpa imbalannya.

Kompilasi Hukum Islam memuat substansi hukum penghibahan yang terdiri dari 5 Pasal mulai Pasal 210 sampai dengan Pasal 214 yaitu:

a) Pasal 210 berisi tentang syarat harta yang akan dihibahkan dengan orang yang menghibahkan.

b) Pasal 211 berisi tentang hibah orang tua kepada anaknya.

c) Pasal 212 berisi tentang pencabutan atau pembatalan hibah.

d) Pasal 213 berisi tentang pemberian hibah dari pemberi hibah yang sudah mendekati ajalnya.

e) Pasal 214 berisi tentang pembuatan surat hibah bagi Warga Negara Asing.

Dalam KHI (Kompilasi Hukum Islam) tersebut disyaratkan selain harus merupakan hak penghibah, penghibah telah pula berumur 21 tahun, berakal sehat dan didasarkan atas kesukarelaan dan sebanyak-banyaknya $1 / 3$ dari hartanya (Pasal 210). Sedangkan hibah yang 
Media Komunikasi dan Informasi Hukum dan Masyarakat

dilakukan oleh orang tua kepada anaknya, kelak dapat diperhitungkan sebagai harta warisan, apabila orang tuanya meninggal dunia (Pasal 211).

Penarikan hibah terhadap harta yang telah dihibahkan tidak mungkin untuk dilakukan, kecuali hibah yang dilakukan orang tua kepada anaknya (Pasal 213). Secara jelasnya ketentuan hibah di dalam Kompilasi Hukum Islam adalah:

\section{Defenisi Hibah}

Secara etimologi kata hibah adalah bentuk masdar dari kata wahaba, yang berarti pemberian. ${ }^{10}$ Sedangkan hibah menurut istilah adalah akad yang pokok persoalannya, pemberian harta milik orang lain di waktu ia masih hidup tanpa imbalan. ${ }^{11}$

Menurut Kompilasi Hukum Islam (KHI) dalam Pasal 171:g mendefinisikan hibah sebagai berikut: "Hibah adalah pemberian suatu benda secara sukarela dan tanpa imbalan dari seseorang kepada orang lain yang masih hidup untuk dimiliki. ${ }^{12}$ Kedua definisi di atas sedikit berbeda, akan tetapi pada intinya sama, yaitu hibah merupakan pemberian sesuatu kepada orang lain atas dasar sukarela tanpa imbalan.

Hibah dari segi bahasa ialah suatu pemberian yang diberikan bukan karena tanggung jawab tertentu dan pemberian ini memberi manfaat kepada penerima. Menurut istilah syara', hibah ialah suatu akad yang dapat

10 Ahmad Warson Al-Munawir.. Kamus Arab Indonesia, Pondok Pesantren, Al-Munawir, Yogyakarta, 1992, hal. 1692.

11 Sayyid Sabiq, sebagaimana dikutip oleh Amir Syarifuddin. 1985. Pelaksanaan Hukum Waris dalam Lingkungan Minangkabau. Jakarta, Gunung Agung. hal. 156.

12 Abdurrahman. 1992. Kompilasi Hukum Islam di Indonesia. Cet, ke-1, Akademika Pressindo, Jakarta, hal. 156. memindahkan milik sesuatu tanpa barang gantian ketika masih hidup dan dibuat secara sukarela. Menurut Kamus Dewan, hibah diartikan sebagai pemberian hak (harta) secara sukarela kepada orang lain dengan tujuan baik. Selain hibah, pemberian dalam bahasa Arab juga disebut Tabarru' dan 'Atiyah. Hibah merupakan pemberian kepada seseorang karena sesuatu penghargaan atau kasih sayang kepadanya.

Dasar hukum pemberian hibah terdapat pada Firman Allah S.W.T dalam Surah AnNisa'(4): ayat 4 yang artinya:

Berikanlah maskawin (mahar) kepada wanita (yang kamu nikahi) sebagai pemberian dengan penuh kerelaan. Kemudian jika mereka menyerahkan kepada kamu sebagian dari maskawin itu dengan senang hati, maka makanlah (ambillah) pemberian itu (sebagai makanan) yang sedap lagi baik akibatnya. ${ }^{13}$

Dalil dari hadist Nabi Saw, yaitu Khalid bin `Adi al-Jahni telah berkata:

Saya mendengar Rasulullah S.A.W
bersabda yang
"Bartinya:
"Bangsiapa diberikan kebaikan
oleh saudaranya bukan karena ia
minta dan dengan tidak berlebih-
lebihan, maka terimalah dan
janganlah ditolak karena
sesungguhnya kebaikan tersebut
merupakan rezeki yang Allah
berikan kepadanya". (Riwayat
Ahmad) $^{14}$

Dengan demikian, baik ayat maupun hadist di atas, menurut Jumhur Ulama menunjukkan (hukum) anjuran untuk saling membantu antar sesama manusia. Oleh sebab itu, Islam sangat menganjurkan seseorang yang mempunyai kelebihan harta untuk menghibahkannya kepada orang yang

13 Ibid., hal. 115

${ }^{14}$ Sayyid Sabiq, op.cit., hal. 193. 
Media Komunikasi dan Informasi Hukum dan Masyarakat

memerlukannya. ${ }^{15}$ Menurut Ali Ahmad Al-Jurjawi yang dikutip Masjfuk Zuhdi, bahwa Islam menganjurkan agar umat Islam suka memberi, karena memberi lebih baik daripada menerima. Pemberian harus ikhlas, tidak ada pamrih/motif apa-apa, kecuali untuk memberi karena keridhaan Allah dan untuk mempererat tali persaudaraan/persahabatan. ${ }^{16}$

Pembatalan hibah menurut pasal 212 Instruksi Presiden No. 1 Tahun 1995 tentang Kompilasi Hukum Islam, menjelaskan bahwa: hibah tidak dapat ditarik kembali, kecuali hibah orang tua kepada anaknya. Sedangkan Jumhur ulama berpendapat bahwa haram hukumnya menarik kembali hibah yang telah diberikan, kecuali hibah seorang ayah kepada anaknya. Berdasarkan hadist Rasululllah SAW yang diriwayatkan oleh Bukhari dan Muslim:

"Orang yang menarik kembali haknya adalah seperti seekor anjing yang muntahmuntah kemudian dia makan kembali muntahnya itu kembali'17

\section{B. Pembatalan Hibah Orang Tua Terhadap Anak Kandungnya Dalam Perspektif Kompilasi Hukum Islam}

Hukum adalah tolak ukur dalam menegakkan sebuah keadilan. Dalam sebuah keadilan Majelis hakim harus menciptakan kepastian hukum dalam menjalankan tugas dan fungsinya dalam memutus dan mengadili perkara Pengadilan. Gustav Radbruch juga mengatakan bahwa tujuan hukum adalah semata-mata untuk menciptakan kepastian hukum, karena dengan adanya kepastian hukum, fungsi hukum dapat berjalan dan mampu mempertahankan ketertiban. Kepastian

\footnotetext{
15 Ibid, hal. 76 .

${ }_{16}$ Masjfuk Zuhdi, Studi Islam, Rajawali Press, Jakarta, 1998, hal. 75

17 Abdul Manan, loc. Cit.
}

hukum adalah syarat mutlak setiap aturan, persoalan keadilan dan kemanfaatan hukum bukan alasan pokok dari tujuan hukum tetapi yang penting adalah kepastian hukum. ${ }^{18}$

Penarikan kembali atas hibah adalah merupakan perbuatan yang diharamkan meskipun hibah itu terjadi antara dua orang yang bersaudara atau suami isteri. Adapun hibah yang boleh ditarik hanyalah hibah yang dilakukan atau diberikan orang tua kepada anak-anaknya.

Dasar hukum ketentuan ini dapat ditemukan dalam hadits Rasulullah SAW yang diriwayatkan oleh Abu Daud, An- Nasa'i, Ibnu Majah dan At-Tirmidzi yang artinya berbunyi sebagai berikut :

"Dari Ibnu Abbas dan Ibnu 'Umar bahwa
Nabi Muhammad SAW bersabda :
"Tidak halal bagi seorang lelaki untuk
memberikan pemberian atau
menghibahkan suatu hibah, kemudian
dia mengambil kembali pemberiannya,
kecuali hibah itu dihibahkan dari orang
tua kepada anaknya. Perumpamaan
bagi orang yang memberikan suatu
pemberian kemudian dia rujuk di
dalamnya (menarik kembali
pemberiannya), maka dia itu bagaikan
anjing yang makan, lalu setelah anjing
itu kenyang ia muntah, kemudian ia
memakan muntah itu kembali.
Di dalam Kompilasi Hukum Islam, masalah penarikan kembali harta yang dihibahkan adalah sangat dilarang. Dalam hal penarikan hibah ini ada juga pengecualian-pengecualian. Seperti hibah orang tua kepada anak kandungnya, diperbolehkan menarik kembali hibah orang tua kepada anaknya. Akan tetapi apabila wahib menarik kembali hibahnya tanpa adanya persetujuan dari mauhublah atau tanpa keputusan pengadilan dan hibahnya itu sudah diserahkan, maka hal tersebut tidak diperbolehkan. Wahib

${ }^{18} / \mathrm{bid}$. 
Media Komunikasi dan Informasi Hukum dan Masyarakat

dianggap sebagai orang yang merampas harta orang lain.

Jumhur Ulama berpendapat bahwa pencabutan di dalam hibah adalah haram, sekalipun hibah itu terjadi diantara saudara atau suami isteri, kecuali bila hibah itu hibah dari orang tua kepada anaknya. ${ }^{19}$ Demikian pula dalam Pasal 212 Kompilasi Hukum Islam dengan tegas menyatakan bahwa hibah tidak dapat ditarik kembali kecuali hibah orang tua kepada anaknya.

Mazhab Imam Malik, Syafi'i dan Zhahir dari Mazhab Imam Ahmad menyatakan bahwa orang tua boleh menarik kembali apa yang telah dihibahkannya kepada anaknya. Dalam hal penarikan hibah orang tua kepada anaknya mempunyai syarat-syarat sebagai berikut: ${ }^{20}$

Pertama, harta yang dihibahkan masih dalam hak milik anak. Jika hak milik sudah keluar (telah berpindah tangan) dari anaknya, seorang ayah tidak boleh menarik kembali hibahnya karena berarti pembatalan hak milik orang lain. Jika barang hibah yang telah menjadi hak milik orang lain itu kembali lagi kepada anaknya dengan sebab yang baru, seorang ayah tidak boleh menariknya kembali karena harta hibahnya itu telah kembali kepada anaknya dengan kepemilikan baru yang tidak diperoleh melalui dirinya.

Kedua, hak melakukan tashasrruf (membelanjakan) terhadap barang yang

19 Sayyid Sabiq, Fikih Sunnah 12, PT. Alma'arif, Bandung, 1987, hal. 191.

20 Abdullah Bin Muhammad Ath-Thayyar, Abdullah Bin Muhammad Al-Muthlaq, Muhammad Bin Ibrahim Al-Musa, Al-Fiqhul-Muyassar Qismul-Muamalat, Mausu'ah Fiqhiyyah Haditsah Tanawalu Ah-Kamal-Fiqhil-Islami Bi Uslub Wadhih Lil-Mukhtashshin Wa Ghairihim, terj. Miftahul Khairi, hal.. 484 dihibahkan itu masih dalam penguasaan anaknya.

Ketiga, penarikan kembali terhadap hibah tidak berhubungan dengan kesenangan orang lain selain anaknya. Jika berhubungan dengan kesenangan kepada selain anaknya, misalnya ia menghibahkan sesuatu kepada anaknya, kemudian karena hibahnya itu orangorang tertarik untuk bergaul (bermuamalah) dengan anaknya itu: mereka berhutang kepadanya atau menikahkan dengan putrinya atau menikahinya jika seorang perempuan, dalam hal ini ada dua pendapat sebagaimana berikut:

a. Orang tua tidak boleh menarik kembali hibahnya. Inilah pendapat Malik dan salah satu riwayat dari Ahmad karena penarikan kembali itu berhubungan dengan selain hak anaknya. Penarikan kembali itu berarti membatalkan haknya.

b. Orang tua boleh menarik kembali hibah yang diberikan kepada anaknya karena hadis Nabi SAW bersifat umum. Selain itu, karena hak orang yang menikah dan orang yang berhutang tidak berhubungan dengan barang yang dihibahkan. Karenanya, hal itu tidak dapat menghalangi penarikan kembali hibahnya.

Keempat, hibah tidak bertambah dengan tambahan yang tidak terpisah (bersambung), seperti menjadi gemuk dan besar serta diketahui bahwa tambahan itu diusahakan. Jika hibah bertambah secara fisik.

Jadi, dalam Kompilasi Hukum Islam penarikan hibah kembali setelah ada penyerahan itu tidak diperbolehkan, akan tetapi juga ada pengecualian-pengecualian seperti yang telah dijelaskan di atas. 
Media Komunikasi dan Informasi Hukum dan Masyarakat

\section{Penutup.}

Hibah adalah pemberian yang dilakukan oleh seseorang kepada pihak lain yang pelaksanaannya dilakukan pada waktu penghibah masih hidup. Hibah dalam hukum manapun pada dasarnya tidak dapat dibatalkan, tetapi apabila memenuhi syarat-syarat tertentu hibah dapat dibatalkan.

Perkara hibah dilarang untuk ditarik kembali. Penarikan kembali atas sesuatu pemberian (hibah) adalah merupakan perbuatan yang diharamkan meskipun hibah tersebut antara dua orang bersaudara atau suami istri. Adapun hibah yang dapat ditarik kembali hanyalah hibah yang dilakukan atau diberikan orang tua kepada anaknya.

Alasan penarikan hibah orang tua kepada anak yang disebabkan si Anak tidak merawat orang tuanya banyak terjadi di masyarakat. Pada akhirnya orang tua sebagai Penggugat memilih untuk membawa kasus ini ke pengadilan dengan harapan Penggugat dapat mengambil kembali yang telah dihibahkan dengan tujuan untuk biaya kelangsungan hidupnya dan agar dapat tetap menjaga hubungan baik dengan anak-anaknya. Majelis hakim berupaya agar pihak Penggugat dan Tergugat berdamai secara kekeluargaan.

Jika tidak berhasil, maka hakim meneruskan acara pada pemeriksaan perkara yang diakhiri dengan keputusan hakim. Meski secara KHI penarikan hibah orang tua kepada anak dapat ditarik apabila penerima hibah tidak memenuhi syarat. Namun dalam hal ini hakim akan memberikan pertimbangan hukumnya berdasarkan

pemeriksaan

selama

persidangan.

Dalam pernyataan penggugat pihak tergugat tidak pernah menafkahi dan memberikan biaya pengobatan perhadap penggugat dan bahkan Tergugat melakukan pencurian dan percobaan pembunuhan terhadap Penggugat.

Apabila pernyataan Penggugat ini dibenarkan berdasarkan saksi dan penyelidikan perkara maka hibah dapat dibatalkan dan ditarik.

Di dalam pasal 212 Kompilasi Hukum Islam ditegaskan bahwa hibah tidak dapat ditarik kembali kecuali hibah dari orang tua kepada anak kandungnya. Berdasarkan pasal 212 Kompilasi Hukum Islam tersebut dapat disimpulkan bahwa tanpa sebab apa pun orang tua dapat menarik kembali atau membatalkan hibah kepada anak kandungnya, apalagi dalam hal orang tua berada dalam keadaan miskin dan sakit-sakitan, maka alasan pembatalan hibahnya cukup rasional. 
Media Komunikasi dan Informasi Hukum dan Masyarakat

\section{DAFTAR PUSTAKA}

\section{A. Buku}

Abdul Manan. 2006. Aneka Masalah Hukum Perdata Islam di Indonesia. Jakarta: Kencana.

Abdurrahman. 1992. Kompilasi Hukum Islam di Indonesia. Jakarta: Akademika Pressindo.

Ahmad Warson Munawir Al-Munawir. 1992. Kamus Arab Indonesia Yogyakarta

Anisitus Amanat. 2001. Membagi Warisan Berdasarkan Pasal-Pasal Hukum Perdata BW. Jakarta: PT Grafindo Persada.

Budiono. 2005. Kamus IImiah Popular Internasional. Surabaya : Alumni.

Sayyid Sabiq. 1985. Pelaksanaan Hukum Waris dalam Lingkungan Minangkabau. Jakarta: Gunung Agung.

------.1987. Fikih Sunnah. Bandung: PT. Alma'arif.

Sudarsono, 1992, Kamus Hukum, PT Rineka Cipta, Jakarta

Subekti, 2001. Hukum Perjanjian, Intermasa. Jakarta.

Wirjono Projodikoro. 1980. Asas-asas Hukum Perjanjian. Jakarta: Sumber Bandung.

Zuhdi, Masjfuk. 1998. Studi Islam. Jakarta: Rajawali Press.

\section{B. Peraturan Perundang-Undangan}

Kitab Undang-Undang Hukum Perdata.

Instruksi Presiden (Inpres) Nomor 1 tahun 1991 tentang Kompilasi Hukum Islam.

Undang-Undang No. 1 Tahun 1974 Tentang Perkawinan.

Kompilasi Hukum Islam

\section{Putusan}

Keputusan Pengadilan Agama Medan No. 1934/Pdt.G/2013/PA.Mdn.

\section{Internet}

http://www.academia.edu/5598317/Pelaksanaan _Prinsip_Hibah_dalam_Produk_Kewan gan_Islam 